\title{
Nie ma wolności bez odpowiedzialności
}

STRESZCZENIE. Analizujemy system organizacji nauki i jego zmiany w Polsce w ostatnim ćwierćwieczu, w kontekście zmian równolegle zachodzących na świecie. W oparciu o nasze doświadczenia z pracy w Międzynarodowym Instytucie Biologii Molekularnej i Komórkowej w Warszawie, ale także dzięki dobrym wzorcom z innych instytucji w Polsce i za granicą, przedstawiamy nasze przemyślenia w odpowiedzi na pytanie, jak rozwijać naukę w Polsce. Uważamy, że aby usprawnić system organizacji nauki w naszym kraju i szybko osiągnąć pozytywny efekt, należy skorzystać ze sprawdzonych wzorów z innych krajów oraz pozytywnych przykładów własnych polskich sukcesów. Realizacja tych zadań wymaga odważnych decyzji politycznych, które zapewnią naukowcom niezbędną do efektywnej pracy wolność, ale także powiążą tę wolność z odpowiedzialnością. Dzięki ludziom, którzy się tego podejmą i odpowiedzialnie wykorzystają oferowane możliwości, Polska będzie miała szansę na szybki postęp cywilizacyjny. Inwestycje w naukę są kluczowe dla rozwoju każdego kraju.

SŁOWA KLUCZOWE: organizacja nauki, wolność, odpowiedzialność, doskonałość kadry, odbiurokratyzowanie, ekspercki system ocen

\section{Wzorce i propozycje na rzecz rozwoju nauki w Polsce ${ }^{1}$}

Poniższy artykuł jest próbą znalezienia odpowiedzi na pytanie, jak rozwijać naukę w Polsce. Punktem wyjścia jest analiza tego, co działo się w systemie organizacji

${ }^{1}$ Część tekstu napisali obaj współautorzy (pkt 1, 3, 4), a część jeden z nich (pkt 2), ale wspólnie stworzyli całość i w pełni akceptują jej treść. Autorzy dziękują współpracownikom z Międzynarodowego Instytutu Biologii Molekularnej i Komórkowej: profesorom Jackowi Jaworskiemu, Marcie Miączyńskiej i Marcinowi Nowotnemu za pomoc oraz wnikliwe i krytyczne uwagi do tekstu oraz Dominice Dubickiej-Boroch za pomoc w zredagowaniu ostatecznej wersji artykułu. 
nauki w naszym kraju w ciągu ostatnich 26 lat, w odniesieniu do rozwoju nauki na świecie.

Nasze rozważania rozpoczynamy od gorzkiego stwierdzenia, że większość polityków w Polsce nie docenia znaczenia nauki nie tylko jako rzeczywistego źródła innowacji, ale i jako narzędzia do identyfikacji problemów, sposobów ich rozwiązywania i oceny skutków różnych działań, czyli do prowadzania skutecznej polityki krajowej. W związku z tym, bez radykalnego zwiększenia kapitału intelektualnego, co może się dokonać tylko dzięki odpowiedniemu wzmocnieniu edukacji i nauki oraz jej odpowiedniej popularyzacji, Polska nigdy nie osiągnie poziomu innowacyjności krajów Zachodu czy „tygrysów Azji”. Tylko kraje, które stawiają na innowacje wynikające w znacznym stopniu ze zrozumienia roli nauki i mądrego w nią inwestowania, mają szanse na postęp i rozwój oraz wynikające z nich stabilność gospodarczą i wysoki poziom życia. Do tego potrzebna jest świadomość znaczenia nauki nie tylko wśród polityków (a zwłaszcza polityków decydentów), ale przede wszystkim wśród społeczeństwa. W tym kontekście dużym problemem jest to, że opinię publiczną kształtuje się, odwołując się do emocji i osobistych przekonań (poprzez postprawdę), a nie do faktów podawanych przez ekspertów powołujących się na wyniki badań naukowych. Interesujące spojrzenie na to zjawisko opisane jest m.in. w dwóch wydanych w 2017 r. książkach (Levitan 2017; Nichols 2017).

Lekceważenie znaczenia nauki i naukowców pracujących w Polsce objawiało się i nadal objawia w rozmaity sposób, zwłaszcza przez dezawuowanie ich dokonań oraz krytykę niektórych instytucji naukowych, np. PAN, przez szerzenie postprawd dla celów politycznych, a w szczególności niedostrzeganie możliwości prorozwojowych kraju przez właściwe zreformowanie nauki i szkolnictwa wyższego. Brak wiary w to, iż w Polsce można stworzyć równie dobre zespoły naukowe i innowacyjne jak te działające w najlepszych ośrodkach za granicą, skutkował tym, że nie zdecydowano się na znaczące dofinansowanie nauki i projakościowe zmiany całego systemu. Dobrze, że obecnie ponownie dyskutujemy, jak zreformować naukę i szkolnictwo wyższe, ale mamy poczucie, że ta dyskusja powinna była zdarzyć się i przełożyć na działania wiele lat temu. Niestety, wina jest nie tylko po stronie polityków, ale i po stronie środowiska naukowego, w szczególności osób na stanowiskach decyzyjnych uczelni i instytutów. Niechęć do zmian, myślenie i działanie w kategoriach korzyści własnych instytucji i środowisk zamiast dobra ogólnego, obrona „swojskości” oraz tolerowanie bylejakości to tylko niektóre nasze grzechy.

Tylko ci, którzy zrozumieją, że inwestycje w naukę są kluczowe dla rozwoju kraju, którzy wskażą sposoby wspierania rozwoju nauki i szkolnictwa wyższego i będą umieli wykorzystać wiedzę i rzetelne dane do podejmowania decyzji politycznych, w tym do polityki społecznej (evidence-based policy making), poprowadzą Polskę w kierunku dalszego postępu cywilizacyjnego. Czy mamy obecnie szansę na taką zmianę? Czy dyskusje w ramach Narodowego Kongresu Nauki (NKN) przybliżają nas do znalezienia właściwych reform? Sądzimy, że tak może 
się stać, gdyż po raz pierwszy prowadzona jest tak szeroka i otwarta dyskusja, w której bierze udział wielu przedstawicieli świata nauki z różnych środowisk, z różnych uczelni i instytucji naukowych, do której zaprasza się ekspertów z zagranicy i w której aktywnie uczestniczą nie tylko przedstawiciele obecnej władzy, ale i innych środowisk politycznych. Czy tak się stanie, zależy jednak od tego, kto zadecyduje o ostatecznym kształcie reformy i kto będzie ją realizował: czy sami politycy, czy wspólnie z naukowcami. Jeśli z naukowcami, to z którymi? Na ile realizacja długoterminowej reformy może być ustabilizowana i uniezależniona od wyników wyborów parlamentarnych przez wiele kolejnych lat?

\section{Ocena dotychczasowych zmian w organizacji nauki}

Zanim odniosę się do niektórych propozycji pojawiających się w ramach NKN i przedstawię własne, spróbuję zidentyfikować efekt zmian w organizacji nauki w Polsce, które miały miejsce od 1989 r., i problemy stanu obecnego. Mimo dużej liczby dobrze wyedukowanych młodych ludzi, mimo wielu pozytywnych zmian, ustaw i regulacji, mimo ogromnych funduszy zainwestowanych w infrastrukturę badawczą, w naukę i szkolnictwo wyższe oraz stworzenia dwóch agencji finansujących badania naukowe i rozwój [Narodowego Centrum Nauki (NCN) i Narodowego Centrum Badań i Rozwoju (NCBR)], mimo sukcesów w finansowaniu najlepszych naukowców i zespołów przez Fundację na rzecz Nauki Polskiej, efekty są mniejsze niż powinny i mogły być osiągnięte. Na pytanie, dlaczego tak się stało, można odpowiedzieć następująco:

To ludzie rozwijają naukę, dokonują odkryć, tworzą wynalazki i przekazują wiedzę innym poprzez kształcenie i popularyzację wyników. Badania naukowe, które mają doprowadzić do wielkich odkryć i w niektórych przypadkach skutkować aplikacjami, mogą zrealizować fachowcy, którzy mają poczucie, że to, co robią, jest doceniane, a do tego mają poczucie stabilizacji i wsparcia środowiska, w tym profesjonalnej administracji. Potrzebują zatem takich warunków pracy, które nie obciążają ich działaniami niezwiązanymi bezpośrednio z oczekiwaną od nich rolą. Tymczasem naukowcy i nauczyciele akademiccy w Polsce obarczeni są nadmierną biurokracją, wynikającą z przeregulowania nauki i braku zaufania ze strony różnych urzędów. Dodatkowym obciążeniem jest często konieczność podejmowania dodatkowego zatrudnienia, będąca skutkiem niskich wynagrodzeń w głównym miejscu pracy.

Nie można podejmować trudnych wyzwań naukowych, jeśli wyznacznikiem sukcesu w karier ze naukowej są tytuły, stopnie, punkty, premie, rozliczenia grantów etc., a nie dokonywanie znaczących odkryć, wynalazków i przekazywanie wiedzy innym. Sprowadzanie pracy naukowej do rzemiosła i masowej produkcji nastawionej 
na ilość, a nie na jakość, w celu optymalizacji wyników ewaluacji własnej i instytucji, w której się pracuje, niszczy myślenie o podejmowaniu trudnych wyzwań i rzeczywistych problemach naukowych.

Zwiększając finansowanie nauki i szkolnictwa wyższego, nie zadbano o wypracowanie systemu oceny jakości, który skutecznie weryfikowałby jakość osiągnięć, poziomu kadry naukowej oraz wniosków o wsparcie nowych działań lub kontynuację działań podjętych wcześniej. Doprowadziło to do stagnacji, „chowu wsobnego", obniżenia wewnętrznych wymagań (np. tolerowania rozpraw doktorskich o niskiej jakości), znacznego zestarzenia się kadry kierowniczej i odwrócenia piramidy wiekowej w instytucjach naukowych i wydziałach uczelni. Wiele z nich utrzymuje studia doktoranckie oraz prawa do nadawania doktoratów i habilitacji tylko dla „punktów” i otrzymania odpowiedniej dotacji. Celem wykazania właściwego „potencjału kadrowego” często zatrudnia się emerytowanych naukowców, którzy nie prowadzą już działalności naukowej. Przyczynia się to do rozdrobnienia potencjału naukowego.

Wprowadzając granty $\mathrm{NCN}$, stworzono zunifikowany system dla różnych dyscyplin, zamiast dostosować go do ich specyfiki. Prowadzi to do nieoptymalnego wykorzystywania środków, ponieważ rozdrabnia je tam, gdzie potrzebna jest większa kumulacja lub kieruje je do niewłaściwych grup. Na przykład, małe granty dla doktorantów w naukach humanistycznych mogą być bardzo przydatne, natomiast w naukach przyrodniczych, wymagających znacznej koncentracji zasobów, mogą prowadzić do rozdrobnienia wysiłków.

Bardzo duże fundusze przeznaczono dla NCBR i skierowano na prace wdrożeniowe bez wprowadzenia odpowiednich ułatwień prawnych i finansowo-podatkowych. Jednocześnie, system przyznawania tych środków nie dawał i nadal nie daje gwarancji na ich właściwe wykorzystanie. Nie stworzono systemu recenzji, zapobiegającego niewłaściwym decyzjom. Brakuje sposobów finansowania oraz środków na finansowanie działań pomiędzy badaniami podstawowymi (które jeżeli są skuteczne, kończą się odkryciem i ewentualnie pomysłem na zastosowanie w praktyce) a badaniami przemysłowymi i pracami wdrożeniowymi, które rozpoczynają się od etapu już przetestowanego prototypu. Nie określono, która z agencji (NCN czy NCBR) ma zająć się finansowaniem badań zorientowanych na opracowanie takich prototypów, czyli zastosowaniami praktycznymi, ale „przedwdrożeniowymi”, $\mathrm{np}$. w formie grantów typu proof of concept, analogicznych do tych, które są finansowane przez European Research Council (ERC). Oczekiwanie, iż w ciągu zaledwie kilku lat można wykonać badania podstawowe, stworzyć i przetestować prototypy oraz przygotować produkt do wdrożenia, jest nierealne.

System przyznawania funduszy strukturalnych na naukę przyzwalał na uzyskiwanie środków na obietnice niemożliwe do realizacji. Część środowiska skorzystała z latwych do zdobycia funduszy, rezygnując ze starań o trudniejsze granty oferowane w konkursach programów ramowych Komisji Europejskiej. To dopro- 
wadziło do demoralizacji niektórych środowisk naukowych. Fundusze strukturalne „wydawano”, a nie inwestowano i nie definiowano oczekiwań (poza sprawdzeniem, czy wydatki odpowiednio zaksięgowano). Potem więc nie można było sprawdzić, czy wynik został osiągnięty, czy nie. Ogromną część środków strukturalnych przeznaczono na infrastrukturę badawczą i nowe budynki, bez stworzenia możliwości do jej optymalnego wykorzystywania. Nie brano także pod uwagę kosztów utrzymania nowych inwestycji. Istnieje obawa, że te koszty będą przekraczały możliwości poszczególnych uczelni i instytucji, czego efektem będzie wynajmowanie powierzchni prywatnym użytkownikom, a nie wykorzystywanie ich na potrzeby kształcenia i nauki. Powołano zbyt mało nowych grup badawczych i nie powstały nowe instytuty naukowe z nową kadrą. Nie stworzono warunków do wypełnienia luki pokoleniowej wśród naukowców. Ze względu na emigrację brakuje zdolnych badaczy w wieku średnim, którzy mogliby stanowić grupę potencjalnych liderów dla nowych zespołów; brakuje też wystarczających zachęt do sprowadzenia talentów z zagranicy.

Oprócz krytycznych ocen należy jednak dostrzec wiele pozytywnych zmian, które po 1989 r. dokonały się na polskich uczelniach i w instytutach oraz w formach finansowania nauki. To dzięki nim i nowym funduszom będzie można przeprowadzić kolejne etapy reform. Mimo powyższej krytyki wskazałbym tu na budowę wielu nowoczesnych budynków uczelni wyższych. Setki tysięcy metrów kwadratowych nowych laboratoriów i sal wykładowych stanowią ogromny potencjał rozwojowy. Kolejny znaczny postęp to zakupy aparatury badawczej na uczelniach i w instytutach naukowych, umożliwiającej prowadzenie badań tymi samymi metodami, co w ośrodkach zagranicznych. Kluczowe było także wprowadzenie zasady zróżnicowania finansowania instytucji naukowych i uczelni w zależności od ich osiągnięć oraz wprowadzenie systemu grantowego. Te trzy elementy zmian w nauce umożliwiły wielu naukowcom i grupom badawczym w Polsce osiągnięcie wysokiego poziomu badań porównywalnego z najlepszymi ośrodkami zagranicznymi. Na przykładzie Międzynarodowego Instytutu Biologii Molekularnej i Komórkowej w Warszawie (MIBMiK) opiszę, jak finansowanie instytucji naukowych w zależności od ich osiągnięć oraz system grantowy umożliwiły jego powstanie i rozwój.

Międzynarodowy Instytut Biologii Molekularnej i Komórkowej w Warszawie jest jednym z najmłodszych instytutów w Polsce. Swoją działalność rozpoczął w 1999 r. w oparciu o ustawę sejmową i już od pierwszych rankingów przeprowadzonych przez Komitet Badań Naukowych (KBN), a następnie Ministerstwo Nauki i Szkolnictwa Wyższego, był na czele instytutów zajmujących się działalnością badawczą w obszarze biologii. Można zadać pytanie, jak to możliwe, że kiedy w Polsce fundusze na naukę były ograniczane i następowały poważne zmiany ekonomiczno-polityczne, udało się stworzyć instytut, który skutecznie konkuruje z wiodącymi jednostkami 
naukowymi nie tylko w Polsce, ale i w Europie? W zamierzeniu organizatorów Instytutu utworzenie tej jednostki było eksperymentem, który miał udowodnić, że wprowadzając w Polsce zasady organizacji nauki przetestowane w Europie Zachodniej, można osiągnąć znaczące efekty. Chodziło o instytut, który będzie działał na podobnych zasadach, jak bardzo dobre placówki o międzynarodowej renomie, np. instytuty Maxa Plancka w Niemczech czy Europejskie Laboratorium Biologii Molekularnej (EMBL), o placówkę, o której młodzi polscy naukowcy mogliby powiedzieć, że daje im ona takie same albo nawet lepsze warunki pracy, niż tam gdzie byli wcześniej na stażu za granicą. Sukces tego eksperymentu (przynajmniej w opinii międzynarodowych komentatorów) wskazuje, że powinno się skorzystać z przykładu tego Instytutu i wykorzystać rozwiązania, które okazały się skuteczne (Schiermeier 2003; 2017; Kuźnicki i Miączyńska 2007). O fenomenie MIBMiK i zasadach jego powstania oraz funkcjonowania, a także o wysiłkach naszego zespołu i trudach, jakie napotkaliśmy na swojej drodze, przypominam w ramach dyskusji w czasie Narodowego Kongresu Nauki 2017.

Powstanie Międzynarodowego Instytutu Biologii Molekularnej i Komórkowej w Warszawie jest efektem działań zespołu, którego trzon tworzyło trzech wówczas młodych naukowców (Macieja Nałęcza, Leszka Kaczmarka i Jacka Kuźnickiego) wierzących, że mogą zreformować naukę w Polsce (Nałęcz 1995, Kuźnicki 1995). Mieliśmy wyobrażenie, jak taki instytut powinien być zorganizowany, a jednocześnie byliśmy świadomi, jakie są słabe strony instytutów w Polsce i co trzeba zrobić $\mathrm{w}$ tej nowej instytucji, aby takie problemy się nie pojawiały. Te pomysły wspierał profesor Angelo Azzi, dyrektor instytutu w Bernie, który współpracował z UNESCO. Wsparcie ze strony tej międzynarodowej instytucji pomogło nam przekonać krajowych decydentów o słuszności naszego projektu. Skutkiem tych wszystkich działań było podpisanie międzynarodowej umowy rządu RP z UNESCO o utworzeniu Międzynarodowego Instytutu Biologii Molekularnej i Komórkowej w Warszawie, co nastąpiło w maju 1995 r. w Paryżu (Kuźnicki, Dubicka-Boroch, Witt i Ziemka 2012; Kuźnicki 2013). Był to kluczowy moment, którego efektem stała się ratyfikacja tej umowy przez polski parlament, a następnie uchwalenie ustawy sejmowej o powstaniu Instytutu ${ }^{2}$. Tym samym, ramy jego działania zostały określone przez polityków, którzy zadecydowali o kształcie ustawy. To dzięki tym decyzjom Instytut uzyskał znaczącą samodzielność, a jednocześnie uprawnienia do prowadzenia nowatorskiej, jak na ówczesne polskie warunki, polityki naukowej.

Bez wpływów zewnętrznych byliśmy w stanie wypracowywać właściwe sposoby funkcjonowania, określone procedury i stworzyliśmy własną „kulturę instytutową”. Jej głównymi cechami są: postawienie na wysoką jakość badań naukowych, współpracę i politykę „otwartych drzwi” wewnątrz Instytutu, niekoncentrowanie się na

${ }^{2}$ Ustawa z dnia 26 czerwca 1997 r. o Międzynarodowym Instytucie Biologii Molekularnej i Komórkowej w Warszawie, Dz.U. nr 106, poz. 674. 
tym, co przynosi doraźne efekty (np. ministerialne punkty oceny parametrycznej), ale na tym, co służy rozwiązywaniu poważnych problemów naukowych i wspieraniu rozwoju młodszych pracowników oraz niekoniunkturalna otwartość na współpracę z zespołami spoza Instytutu. Ważna jest także atmosfera typu team spirit, wspólnego wypracowywania kluczowych decyzji i poczucia, iż na każdym poziomie działania w zespołach naukowych i innych działach kreatywność, odpowiedzialność i rzetelność są tym, co decyduje o ostatecznym wyniku, oraz że praca każdego pracownika jest ważna dla sukcesu całego Instytutu.

Działalność Instytutu nadzoruje Międzynarodowy Komitet Doradczy (MKD). W jego skład wchodzi obecnie 18 uczonych, głównie spoza Polski, z dużymi osiągnięciami naukowymi i organizacyjnymi (np. dyrektorzy placówek naukowych), którzy honorowo (bez wynagrodzenia) poświęcają swój czas, aby wspierać rozwój Instytutu, oceniać jego dokonania i plany. Udało nam się przezwyciężyć różne problemy i niebezpieczeństwa, jakie napotykaliśmy na naszej drodze na skutek zmian w ustawodawstwie, zasadach finansowania i nieufności z różnych stron. Nie znaczy to jednak, że wszystkie rozwiązania wprowadzone i przetestowane w MIBMiK okazały się idealne, a tym bardziej nie muszą one nadawać się do bezpośredniego kopiowania przez inne instytucje działające w innych warunkach prawnych.

W ustawie Instytutowi zapewniono budynek należący do Polskiej Akademii Nauk (PAN) oraz, w niewielkiej wysokości, finansowanie podstawowej administracji i kosztów utrzymania tego budynku. Nie przeznaczono jednak żadnych funduszy na zainicjowanie i wspieranie działalności naukowej. Pierwszym kluczowym elementem tworzenia Instytutu było zatrudnienie właściwych liderów naukowych, tj. takich, którzy nie tylko potrafią zdobyć środki finansowe, ale są twórczy i podejmą trudne wyzwania, będą zdolni do uzyskania znaczących wyników i opublikowania ich w bardzo dobrych czasopismach, a także takich, którzy dzięki prowadzeniu nowoczesnych badań na wysokim poziomie są w stanie stworzyć zespół, zatrudniając młodych i zmotywowanych do starań o sukces, ambitnych naukowców. Osobami, do których kierujemy naszą ofertę zatrudnienia jako lidera, są przede wszystkim młodzi stażyści podoktorscy, którzy chcą założyć swój pierwszy zespół badawczy. Sposobem na znalezienie takich liderów jest przeprowadzanie rzetelnych, międzynarodowych konkursów, otwartych dla osób ze stopniem doktora. W procesie tym kluczowi są członkowie wspomnianego powyżej MKD. W każdym konkursie komisja MKD tworzy krótką listę kandydatów, którzy są zapraszani na otwartą sesję naukową, podczas której prezentują swoje wyniki i dyskutują je z pracownikami Instytutu oraz członkami komisji. Następnie członkowie MKD przeprowadzają z każdym kandydatem rozmowę, na podstawie której rekomendują dyrektorowi potencjalnych liderów. Dotychczas w 19 konkursach zatrudniliśmy 16 liderów, w tym kilku z innych krajów. Warto podkreślić, że odbyły się też konkursy bez rozstrzygnięcia, w których MKD nikogo nie rekomendował albo w których negocjacje z rekomendowanym kandydatem zakończyły się niepowo- 
dzeniem. Zdarzały się także sytuacje, w których rekomendowano równocześnie kilku bardzo dobrych kandydatów i kiedy zakładanych było kilka grup badawczych. Taka procedura stwarza optymalne warunki do wybrania osób twórczych, o właściwych cechach, prowadzących badania na światowym poziomie. Udało nam się zatrudnić utalentowanych naukowców, którzy skupiają wokół siebie innych, również utalentowanych współpracowników. Wielu z nich twierdzi, że gdyby nie nasz Instytut, to albo by nie wrócili, albo ponownie wyjechali z Polski. Naukowcy ci są niezwykle skuteczni w pozyskiwaniu środków finansowych na badania ze źródeł polskich i zagranicznych. W przygotowywaniu wniosków grantowych mają mocne wsparcie zarówno administracji, jak i bardziej doświadczonych koleżanek i kolegów.

Zatrudniony w wyniku konkursu kierownik grupy badawczej dostaje do dyspozycji powierzchnię laboratoryjną i biurową, fundusze na swoją pensję, na rozpoczęcie prac badawczych (start-up funds) oraz na stypendia dla dwóch doktorantów. Kierownik grupy równocześnie musi być świadom, że jednym z jego najważniejszych zadań jest zdobywanie funduszy na badania i na zatrudnienie dodatkowych pracowników. Już po kilku latach funkcjonowania zespoły liczą co najmniej 10 osób, co oznacza, że większość z nich jest finansowana z grantów. Konieczność utrzymania większości pracowników naukowych dzięki funduszom grantowym powoduje, iż zarówno kierownik, jak i część jego personelu stale musi zdobywać dodatkowe finansowanie. Są to granty polskie i zagraniczne, w tym fundusze Programów Ramowych Komisji Europejskiej. Wszyscy liderzy i członkowie ich zespołów są zatrudniani na okresowych kontraktach. Przedłużenie kontraktu jest możliwe tylko dzięki utrzymaniu badań naukowych na bardzo wysokim poziomie. Każdy zespół badawczy jest oceniany po raz pierwszy po 3 latach przez członków MKD i powołanych przez nich specjalistów w danej dziedzinie. Rekomendują oni dalsze postępowanie z zespołem. Jeśli optują za przedłużeniem umowy, wówczas dodajemy do oryginalnego kontraktu kolejne 2 lata. Takie „przesuwane” zatrudnienie typu rolling-tenure teoretycznie może trwać w nieskończoność, ale były już rekomendacje negatywne, gdzie kierownik i członkowie zespołu mieli jedynie czas do wygaśnięcia kontraktu, czyli ok. 1,5 roku, na znalezienie innej pracy. Dotychczas rozwiązano siedem zespołów: dwa z powodu opinii MKD, a pozostałe w wyniku decyzji kierowników grup o przeniesieniu się do innych instytucji. Jednym z tych ostatnich jest prof. Agnieszka Chacińska, która po 7 latach pracy w Instytucie wygrała konkurs na dyrektora Centrum Nowych Technologii Uniwersytetu Warszawskiego (CeNT UW) i obecnie tam pracuje.

Eksperymentowanie jest pouczające, zwłaszcza kiedy wyniki eksperymentu analizuje się krytycznie i wyciąga wnioski zarówno z sukcesów, jak i z ich braku. Nie wszystkie pierwotne pomysły na funkcjonowanie Instytutu okazały się słuszne. Jednym z takich elementów jest brak możliwości stałego zatrudnienia dla kierowników zespołów badawczych, którzy przeszli pozytywnie przez kilka kolejnych ocen. Nawet 
po kilkunastu latach pracy kierownikzespołu niemoże czuć sięstabilnie zatrudniony, co powoduje, że musi myśleć o działaniach, które w kolejnych ewaluacjach zapewnią mu dalsze zatrudnienie. Może to skłaniać do unikania podejmowania bardzo ambitnych projektów, wymagających wielu lat pracy (dłuższych niż okresy pomiędzy ewaluacjami). Kolejnym problemem jest bardzo częsta ewaluacja zespołów (co 2 lata), co również zbytnio angażuje członków MKD w trakcie ich wizyt w Instytucie. W oparciu o nasze doświadczenia uważamy, że częstość ewaluacji powinna się zmniejszać wraz z zaawansowaniem kariery, tak aby dojrzali i wielokrotnie już oceniani badacze przechodzili poważną ocenę okresową co 5-6 lat.

W Instytucie było i jest realizowanych wiele grantów z 5., 6. i 7. Programu Ramowego Komisji Europejskiej. Dwóch naukowców (Janusz Bujnicki i Marcin Nowotny) otrzymało granty European Research Council, a jeden grant ERC jest realizowany w Londynie przez dr Ewę Paluch, która uzyskała go jako kierowniczka grupy afiliowanej przy MIBMiK i Instytucie Maxa Plancka w Dreźnie. Warto zaznaczyć, że już na początku istnienia Instytutu stworzyliśmy dział wspierający naukowców w aplikowaniu o granty i przygotowywaniu raportów, głównie po to, aby odciążyć ich od pracy administracyjnej. Naukowcy mają pełne wsparcie profesjonalnych pracowników administracji. Ze względu na międzynarodowy charakter Instytutu i obecność wielu naukowców niemówiących po polsku, od wszystkich pracowników administracji, księgowości i innych działów wspierających wymaga się znajomości języka angielskiego. Profesjonalizm takich pracowników oraz ich poczucie, że tworzą razem z naukowcami jeden zespół, jest jednym z kluczowych elementów odpowiedzialnych za sukcesy Instytutu.

O tym, że idea stojąca u podstaw powołania do życia międzynarodowego instytutu badawczego odniosła sukces, świadczy wiele danych, np. liczba, jakość i cytowania prac, liczba grantów i wielkość finansowania grantowego, stanowiska badawcze składające się z unikatowych i nowoczesnych urządzeń, ekspertyza pracowników skutkująca umowami z przedsiębiorcami, rozbudowana współpraca w kraju i za granicą, a także patenty i związane z nimi licencje. W latach 2000-2016 pracownicy MIBMiK opublikowali ponad 800 prac naukowych z Impact Factor, w tym w: Cell, EMBO Journal, FASEB Journal, Glia, Human Mutation, Journal of Biological Chemistry, Journal of Neuroscience, Molecular Cell, Molecular Psychiatry, Nature, Nature Coummunications, Nature Structural and Molecular Biology, Neuron, Nucleic Acids Research, PLoS Biology, PLoS Medicine, PNAS USA, RNA.

W tym samym okresie (2000-2016) w Instytucie realizowano 265 projektów, w tym: 207 projektów krajowych oraz 58 zagranicznych, w tym z EMBO (4 projekty), HHMI (3), Wellcome Trust (3), NIH, Towarzystwa Maxa Plancka, DFG, funduszy polsko-szwajcarskich i polsko-norweskich. W latach 2006-2016 22,7\% finansowania grantowego pochodziło z zagranicy. Ponadto w ramach Programów Ramowych Komisji Europejskiej uzyskano finansowanie 27 projektów na sumę 14,1 mln EUR (7 w 5. PR - 1,9 mln EUR, z czego 2 koordynowane przez MIBMiK; 9 w 6. 
PR - 3,8 mln EUR; $11 \mathrm{w} 7$. PR - 8,4 mln EUR) oraz $12 \mathrm{z}$ funduszy strukturalnych. W latach 2006-2016 71\% funduszy pochodziło ze źródeł konkursowych. Dzięki tym grantom roczny budżet Instytutu wzrósł od 1999 r. (1,5 mln zł) ponad 20-krotnie, osiągając już w 2012 r. poziom ok. $32 \mathrm{mln}$ zł i utrzymując się z drobnymi wahaniami do 2015 r. W 2016 r. wzrósł do ok. 37 mln zł. Obecnie w Instytucie pracuje ponad 180 osób, w tym 41 doktorantów. Suma funduszy zainwestowanych w Instytut od początku jego powstania (pensje, aparatura, odczynniki, wyjazdy naukowe, bieżące rachunki itd.) wynosi ok. 82,5 mln EUR, czyli ok. 330 mln zł. Suma ta wystarczyła, aby w pustym na początku budynku stworzyć i umożliwić funkcjonowanie Instytutowi znajdującemu się obecnie na 1. miejscu (z kategorią A+) w rankingu Ministerstwa Nauki i Szkolnictwa Wyższego wśród placówek prowadzących badania w dziedzinie biologii. Ten sukces był możliwy dzięki temu, że politycy dali nam szansę, uchwalając ustawę o powołaniu Instytutu, a następnie pozwalając nam na realizację idei doskonałości naukowej bez politycznych ingerencji.

Na przykładzie MIBMIK widać, iż dotychczasowe zmiany w organizacji nauki w Polsce nie przeszkadzały, a wręcz stwarzały szanse na powstanie nowych, bardzo dobrych zespołów i instytucji naukowych. W kraju jest także wiele innych przykładów bardzo dobrych zespołów i centrów badawczych, które optymalnie wykorzystały istniejące warunki i możliwości. Niestety, dokonało się w to zbyt małej skali. Co więcej, ich powstanie łączyło się z kompromisami wobec istniejącego środowiska naukowego lub postawieniem na utrzymanie infrastruktury kosztem jakości zespołów i ich pracy naukowej. Są też przykłady błędnych decyzji, polegające na znacznych wydatkach na infrastrukturę, która generuje koszty, a nie na zasoby ludzkie, wyniki naukowe, publikacje oraz aplikacje. Zarówno pozytywne, jak i negatywne przykłady powinny posłużyć do opracowania zasad dalszych działań reformujących. Wiele uczelni wybudowało nowe budynki, zakupiło aparaturę, ale nie mają możliwości, aby utrzymać ich funkcjonowanie i wypełnić je bardzo dobrymi zespołami naukowymi. W takich miejscach mogą powstawać nowe instytuty jako centra badawcze tych uczelni i skutecznie konkurować z najlepszymi instytutami w Polsce i za granicą. W tym celu należy wykorzystać doświadczenia w organizacji nowych instytucji, nie tylko MIBMiK w Warszawie, ale i np. Centrum Nowych Technologii Uniwersytetu Warszawskiego, Centrum Zaawansowanych Materiałów Politechniki Warszawskiej, Małopolskiego Centrum Biotechnologii Uniwersytetu Jagiellońskiego i EIT+ we Wrocławiu.

\section{Nasze propozycje}

Co można zrobić, aby usprawnić system nauki w Polsce i szybko osiągnąć maksymalnie pozytywny efekt? Przede wszystkim skorzystać ze sprawdzonych wzorów 
z innych krajów oraz pozytywnych przykładów naszych krajowych sukcesów. Dotyczy to nie tylko naszej macierzystej placówki, co szczegółowo opisujemy, ale i innych instytucji, np. w Poznaniu, Krakowie i Warszawie, działających w „starych” ramach organizacyjnych. Na podstawie naszych doświadczeń w Międzynarodowym Instytucie Biologii Molekularnej i Komórkowej oraz znajomości wzorców krajowych i zagranicznych proponujemy następujące działania w zakresie tworzenia nowych jednostek naukowych oraz reformowania niektórych istniejących jednostek w kierunku radykalnej koncentracji działalności naukowej na podjęciu konkurencji na poziomie światowym.

\subsection{Propozycje dotyczące systemu nauki}

1. Niezbędne jest przyjęcie bezkompromisowego podejścia dotyczącego doskonałości kadry, zarówno jeżeli chodzi o naukowców, jak i pracowników administracji. Od ich zaangażowania i umiejętności zależy wynik pracy. W tym obszarze organizacji nie można sobie pozwolić na obniżanie standardów w myśl oszczędności, gdyż natychmiastową konsekwencją jest obniżenie efektywności. Konieczne jest oferowanie takich warunków finansowych, które umożliwią skuteczną konkurencję o najlepsze kadry na poziomie światowym.

- Niezbędna jest staranna selekcja osób na wszystkie stanowiska. Zwłaszcza w przypadku stanowisk związanych z dużą odpowiedzialnością (zarówno w ramach prowadzenia badań, jak i w administracji) konieczne jest wyznaczenie wysokich standardów, poniżej których nie można zejść, nawet w razie braku odpowiednich kandydatów. Wymaga to wielu działań, np. przeprowadzania otwartych (na kraj i zagranicę) konkursów na stanowiska naukowe, m.in. kierowników grup, stażystów podoktorskich, doktorantów, a także na stanowiska w administracji. Konkursy muszą być prowadzone nie tylko pod kątem wybrania najlepszego przystępującego w danym momencie do konkursu kandydata/najlepszej kandydatki, ale przede wszystkim spełnienia wysokich wymagań odpowiadających docelowemu poziomowi instytucji. Oznacza to dopuszczenie możliwości zamknięcia konkursu bez znalezienia odpowiedniego pracownika, jeżeli najlepszy kandydat nadal nie spełnia oczekiwań (jak wspomnieliśmy wcześniej, w MIBMiK część konkursów na stanowiska kierownicze była zamykana z wynikiem negatywnym, przy założeniu, że konkurs zostanie otwarty ponownie, aż znajdzie się kandydat spełniający oczekiwania). Nie zdarzyło się nam obniżyć oczekiwań, aby dostosować się do poziomu kandydatów. Takie podejście w dłuższej perspektywie owocuje podniesieniem prestiżu instytucji. Podobna praktyka znana jest nam z czołowych instytucji naukowych, np. Politechniki Federalnej w Lozannie (EPFL).

- Pracownicy poddawani są rzetelnej okresowej ocenie, od której zależy przedłużenie ich zatrudnienia. Ocena okresowa powinna odbywać się z udziałem 
ekspertów zewnętrznych i brać pod uwagę opinie płynące z instytucji zatrudniającej. Oczywiście wszyscy pracownicy muszą znać i akceptować tę regułę przed podjęciem zatrudnienia. Na poziomie kierownika grupy badawczej i na wyższych stanowiskach ocena powinna odbywać się na podstawie recenzji zewnętrznych, najlepiej z udziałem ekspertów zagranicznych, którzy powinni ocenić, jak osiągnięcia osoby ocenianej i jej grupy mają się do poziomu osiągnięć w najlepszych jednostkach naukowych w danej dyscyplinie na świecie. Konieczne jest spełnienie dwóch warunków oceny peer review, zgodnie z rekomendacją Komitetu Polityki Naukowej: 1) brak konfliktu interesów (zarówno w sensie pozytywnym, jak i negatywnym), 2) ekspert oceniający musi reprezentować co najmniej taki poziom naukowy, jak osoba oceniana, preferencyjnie wyższy 3 . W MIBMiK przeprowadzana jest regularna ocena okresowa kierowników grup, stanowiąca podstawę przedłużania ich zatrudnienia i działalności grup przez międzynarodowy komitet (MKD) w oparciu o recenzje zagranicznych, anonimowych ekspertów, którzy reprezentują naukę na bardzo wysokim poziomie światowym.

- W przypadku braku rekomendacji do przedłużenia zatrudnienia kierownika i funkcjonowania grupy rozwiązywana jest cała grupa. Nie praktykuje się przejmowania grup przez ich członków „w spadku” po poprzednim szefie. Objęcie stanowiska kierownika grupy jest możliwe tylko na drodze konkursowej i dotyczy wyłącznie tworzenia nowych grup.

- Kierownicy grup, którzy przeszli wiele ewaluacji i wykazali się zarówno podejmowaniem znaczących wyzwań badawczych, jak i skutecznością w doprowadzaniu swoich działań do sukcesu, powinni zostać docenieni poprzez zwiększenie zaufania, a co za tym idzie - znaczne wydłużenie okresu pomiędzy kolejnymi ocenami. Według naszych dotychczasowych doświadczeń, jak i wzorów międzynarodowych (np. oceny osób na stanowiskach dyrektorskich w instytutach Maxa Plancka) dojrzali naukowcy, kierujący dużymi zespołami badawczymi, powinni przechodzić ocenę okresową co 5-6 lat.

2. Niezbędne jest zapewnienie wolności badawczej i organizacyjnej, jak również wymaganie odpowiedzialności proporcjonalnie do tej wolności dla osób kierujących przedsięwzięciami związanymi z nauką, w tym rektorów uczelni, dziekanów wydziałów, dyrektorów instytutów, kierowników laboratoriów itp. W szczególności zarządzający dużymi jednostkami naukowymi powinni mieć swobodę kształtowania wewnętrznej struktury i polityki kadrowej swoich jednostek. Kierujący instytucjami naukowymi powinni również mieć możliwość (i związaną z tym odpowiedzialność) kształtowania polityki kadrowej w taki

3 Stanowisko Komitetu Polityki Naukowej w zakresie wskaźników doskonałości naukowej, Warszawa, http://www.nauka.gov.pl/g2/oryginal/2014_11/45338beo37b189odb6da9d2aeoe83aof.pdf [29.09.2014]. 
sposób, żeby zapewnić odpowiednią mobilność swoich pracowników. Z jednej strony niezbędne jest zapewnienie długoterminowego zatrudnienia dla kluczowych pracowników, z drugiej - zapewnienie, że pracownicy po zrealizowaniu z sukcesem danego etapu kariery opuszczą instytucję i będą kontynuować swoją pracę w innym ośrodku, przenosząc tam swoje doświadczenia i najlepsze praktyki.

- Kierownicy grup badawczych na etapie rekrutacji powinni być wybierani pod kątem dopasowania do profilu badawczego instytucji, ale od momentu wybrania powinni mieć całkowitą wolność w kształtowaniu swojej strategii badawczej, polityki kadrowej i bieżącej działalności, w ramach otrzymanych do dyspozycji zasobów. To, czy ich działania przyniosą sukces czy nie, należy weryfikować w ramach oceny okresowej.

- Okresowa ewaluacja służy ocenie sukcesu kierownika i jego grupy pod względem zainwestowanych w grupę zasobów, przede wszystkim pod kątem jakości wyników pracy naukowej (doskonałość naukowa i/lub użyteczność wyników dla społeczeństwa/gospodarki - w zależności od obszaru nauki), ale także pod kątem wartości dodanej dla instytucji. Naukowcy, którzy wykazują sukcesy w obszarze strategicznych priorytetów instytucji, powinni być mocno wspierani, aby swoje sukcesy zwielokrotnić. Naukowcy, którzy wykazują sukcesy w innym obszarze niż strategiczne priorytety instytucji, powinni otrzymać wsparcie w przeniesieniu się do (lub stworzeniu nowej) instytucji, w której mogliby realizować swoje prace. Alternatywą jest zmiana strategicznych priorytetów instytucji macierzystej.

\subsection{Propozycje dotyczące całego systemu nauki i szkolnictwa wyższego}

3. Należy odbiurokratyzować system nauki i szkolnictwa wyższego, a jego działalność oprzeć na zaufaniu władz wobec naukowców i nauczycieli akademickich. Jednocześnie należy wprowadzić prosty, projakościowy system oceny nauczania, osiągnięć naukowych, innowacyjnych, popularyzacji i innych form działalności związanej z nauką. Należy zrezygnować z dotychczasowej formy ewaluacji jednostek, która prowadzi do zdobywania punktów, a nie do uprawiania nauki na najwyższym możliwym poziomie. W przypadku bardzo dużych uczelni należy wyodrębnić większe części, będące połączeniem wydziałów, reprezentujące określone dziedziny nauki, i to właśnie obszary nauki, a nie poszczególne wydziały, poddawać ocenie.

4. Na podstawie nowego systemu ocen (głównie eksperckiego) należy premiować finansowo instytucje, uczelnie, ich jednostki (lub ich grupy) oraz zespoły naukowe, które mają najlepsze wyniki. Dodatkowe fundusze należy również inwestować we wsparcie zatrudniania młodszych pracowników, osób decydu- 
jących się na jednoetatowość, na zwiększanie współpracy i mobilności krajowej, tworzenie nowych zespołów naukowych i podejmowanie nowych kierunków badawczych. Należy stopniowo zwiększać finansowanie nauki, wspierając przede wszystkim ludzi (wyższe wynagrodzenia dla osób, które odnoszą sukcesy) i ich działalność naukową w zespołach i instytucjach z najlepszymi wynikami oraz dodatkowo, na realizację krajowych projektów zamawianych we wszystkich dziedzinach, w tym w naukach społecznych i humanistycznych.

5. Państwowe uczelnie wyższe powinny określić się albo jako badawcze, tj. prowadzące badania naukowe i kształcenie, albo jako uczelnie zorientowane głównie na kształcenie, których celem jest przede wszystkim przekazywanie wiedzy i kulturotwórcza działalność w określonym regionie kraju. Do tego podziału powinno być dostosowane finansowanie oraz zdefiniowane oczekiwania wobec pracowników. Z trzech elementów takich, jak kształcenie, prowadzenie badań naukowych oraz oddziaływanie nauki na otoczenie (czyli współdziałanie w praktycznym zastosowaniu wynalazków i aplikacji, popularyzacji i upowszechniania nauki) należy stworzyć spójny system. Jakość każdego z tych elementów powinna determinować ostateczny wynik oceny i finansowanie poszczególnych instytucji.

- Do oceny kształcenia doskonale nadaje się monitorowanie losów absolwentów: ilu pozostało w nauce czy na uczelniach, ilu i po jakim czasie zrobiło doktoraty, ilu pracuje w czołowych placówkach naukowych krajowych i zagranicznych i na jakich stanowiskach, ilu uczy w szkołach wyższych i ilu zostało nauczycielami zatrudnionymi w edukacji, ilu zajmuje ważne stanowiska w firmach etc. Liczba studentów lub liczba obronionych prac inżynierskich i magisterskich nie jest właściwym parametrem oceny działania szkoły wyższej, gdyż niewiele mówi o sukcesie zawodowym absolwentów. Oceniającymi mogliby być eksperci, urzędnicy, odpowiednio zreformowana Państwowa Komisja Akredytacyjna (PKA).

- System oceny powinien być prosty i weryfikowalny. Można rozważyć wprowadzenie systemu opartego na ograniczonej liczbie kryteriów. Na przykład w Holandii finansowanie uczelni zależy od liczby wypromowanych doktorantów. W Niemczech i Norwegii obowiązuje zasada, że doktorant musi być pierwszym autorem w co najmniej dwóch pracach w czasopismach o określonej reputacji. W Polsce dla nauk o życiu mogłyby to być np. prace w czasopismach znajdujących się w górnej połowie listy A dla określonej dziedziny. Taki system ogranicza liczbę słabych doktoratów, a te rozprawy, które są bronione, muszą być oparte na wynikach, które wcześniej zostały zweryfikowane poprzez system recenzji w dobrych międzynarodowych czasopismach naukowych. Tym samym osiąga się dobrą jakość doktoratów i eliminuje prace przyczynkowe.

- Podczas oceny działalności naukowej należałoby brać pod uwagę jakość publikacji oraz skuteczność pozyskiwania finansowania grantowego z konkur- 
sowych źródeł polskich i zagranicznych, jak również uzyskanie prestiżowych nagród przyznawanych przez międzynarodowe instytucje. Taką ocenę powinien przeprowadzać Komitet Ewaluacji Jednostek Naukowych (KEJN) oraz odpowiedni eksperci.

- Do oceny oddziaływania nauki z otoczeniem należałoby brać pod uwagę liczbę uzyskanych patentów o co najmniej europejskim zasięgu i udokumentowane wpływy z przyznanych licencji, skutecznych wdrożeń w gospodarce i polityce publicznej, płatnych przez przemysł ekspertyz, utworzonych spółek mających określony kapitał czy przychody ze sprzedaży. Oprócz komercjalizacji należy także odpowiednio docenić oddziaływanie społeczne i kulturowe instytucji, w tym innowacje społeczne i działania popularyzujące naukę (biorąc pod uwagę skalę i efekty takich działań).

6. Należy uprościć prawo związane z działalnością innowacyjną i aplikacyjną w taki sposób, aby zakładanie spółek na bazie odkryć naukowych było łatwe i szybkie oraz podatkowo bezpieczne zarówno dla twórców, jak i dla instytucji, z których pochodzą. Nie powinno się oczekiwać szybkich korzyści finansowych z takich działań (wiara w szybkie efekty jest bowiem nieuzasadniona). Trzeba zmodyfikować system recenzji projektów NCBR w taki sposób, aby ograniczyć lobbing i potencjalne nadużycia.

7. Należy przeprowadzić audyt wydatków państwa na inwestycje w krajową infrastrukturę badawczą oraz na współpracę z zagranicą pod kątem sposobu korzyści dla kraju, liczby osób korzystających z infrastruktury oraz opracować długoletni plan takich wydatków, biorąc pod uwagę kierunki rozwoju nauki i dziedzin o największym potencjale rozwojowym.

8. Należy wprowadzić możliwość rozwiązywania placówek i powoływania nowych instytucji naukowych podejmujących nowe wyzwania, wynikające ze zmian cywilizacyjnych. Na wzór Towarzystwa Maxa Plancka takie nowe placówki powinny być tworzone przez wybitnego naukowca w danej dziedzinie. Należy stworzyć warunki zachęcające do pracy w Polsce wybitnych naukowców i wprowadzić system umożliwiający racjonalną zmianę pokoleniową na kierowniczych stanowiskach w placówkach naukowych.

9. Należy również powstrzymać spadek etosu nauki i prestiżu naukowców. Trzeba wprowadzić skuteczny system kontroli oszustw i nadużyć naukowych, w szczególności związanych z plagiatami, autoplagiatami, publikowaniem pseudonaukowych wyników, uprawianiem turystyki naukowej, pisaniem grzecznościowych, koleżeńskich recenzji, ukrywaniem konfliktu interesów i wspólnot interesów oraz prowadzeniem i popieraniem wszelkich form nepotyzmu. W USA planuje się stworzenie Research Integrity Advisory Board (RIAB), aby przeciwdziałać tym zjawiskom, wpływającym m.in. na obniżenie prestiżu nauki w społeczeństwie (Mervis 2017). 


\section{Postulaty dla polityków jako podsumowanie naszych przemyśleń}

Naszym zdaniem głównymi elementami polityki naukowej państwa powinny być:

1. Radykalne odbiurokratyzowanie wszystkich form działalności naukowej, w tym ograniczenie do minimum sprawozdawczości na rzecz merytorycznego rozliczania projektów oraz uproszczenie działań umożliwiających komercjalizację wyników badań poprzez odpowiednie zmiany w prawie i zasadach podatkowych dotyczących prowadzenia działalności innowacyjnej.

2. Wykorzystanie kulturotwórczej roli nauki dla rozwoju społeczeństwa poprzez popularyzację i upowszechnianie nauki, zwiększenie roli nauk społecznych i humanistycznych oraz poprzez wsparcie uczelni dydaktycznych w mniejszych ośrodkach akademickich.

3. Wprowadzenie uproszczonej ewaluacji instytucji w oparciu o kryteria jakościowe (rezygnacja z drobiazgowych kryteriów prowadzących do „ciułania punktów", a zwiększenie roli ekspertów).

4. Stworzenie szybkiej ścieżki kariery dla naukowców wybijających się na wczesnym jej etapie w oparciu o osiągnięcia jakościowe, zapewnienie im możliwości wczesnego usamodzielnienia się, np. poprzez prowadzenie własnego zespołu naukowego lub własnych projektów badawczych.

5. Zwiększanie finansowania przede wszystkim dla dobrze ocenionych zespołów, zwiększenie wynagrodzenia dla odnoszących największe sukcesy naukowców oraz dla zatrudniających ich instytucji. Premiowanie tych zespołów, które podejmują nowe, ambitne wyzwania i podwyższenie wynagrodzeń młodych pracowników: doktorantów i asystentów, stażystów podoktorskich i świeżo mianowanych liderów zespołów; docelowo do poziomu, który proponuje się cudzoziemcom lub Polakom powracającym z zagranicy.

6. Stworzenie systemu finansowania konsorcjów krajowych do opracowania konkretnych zagadnień w celu zwiększenia autentycznej współpracy i lepszego wykorzystania infrastruktury i know-how.

\section{Podsumowanie}

Dotychczasowe dyskusje w ramach konferencji stanowiących przygotowanie do Narodowego Kongresu Nauki wskazują, że nasze postulaty podziela wielu naukowców. Ograniczenie biurokracji, zwiększenie społecznego zaangażowania nauki i wsparcie współpracy nauki z gospodarką to także cele deklarowane przez Ministerstwo Nauki i Szkolnictwa Wyższego. Realizacja tych zadań wymaga odważnych decyzji, takich, które zapewnią naukowcom niezbędną do efektywnej pracy wolność, ale 
i powiążą tę wolność z odpowiedzialnością. Chcąc, aby nauka w Polsce rozwijała się na miarę jej rzeczywistego potencjału, głównych celów nie można rozmienić na drobne. Mamy nadzieję, że dyskusja o nauce w Polsce, w której uczestniczymy, doprowadzi do stworzenia wewnętrznie spójnego i sprawiedliwego systemu, opartego na zaufaniu i kompetencjach merytorycznych, który będzie dobry nie tylko dla naukowców, ale i dla wszystkich tych, którzy z pomocy nauki mogą skorzystać.

\section{Literatura}

Kuźnicki, J. (1995). Międzynarodowy Instytut Biologii Molekularnej i Komórkowej w Warszawie. W poszukiwaniu optymalnego modelu. Nauka. 4: 57-62.

Kuźnicki, J. (2013). „Mamy twórczych i zdolnych naukowców” - o funkcjonowaniu Międzynarodowego Instytutu Biologii Molekularnej i Komórkowej w Warszawie. Wywiad z prof. Jackiem Kuźnickim. Biotechnologia.pl.

Kuźnicki, J., Dubicka-Boroch, D., Witt, M., Ziemka, A. (2012). Rola Akademii w powstaniu Międzynarodowego Instytutu Biologii Molekularnej i Komórkowej w Warszawie. $\mathrm{Na}$ uka. 2: 81-84.

Kuźnicki, J., Miączyńska, M. (2007). Opportunities in Poland. Nature. 446: 580. doi:10. 1038/nj7135-58ob.

Levitan, D. (2017). Not a Scientist: How Politicians Mistake, Misrepresent and Utterly Mangle Science. New York: W.W. Norton \& Co..

Mervis, J. (2017). U.S. Report calls for Research integrity board. Science. 356(6334): 123.

Nałęcz, M. (1995). Międzynarodowy Instytut Biologii Molekularnej i Komórkowej w Warszawie. Historia, stan aktualny i zamierzenia. Nauka. 4: 53-56.

Nichols, T. (2017). The Death of Expertise: The Campaign Against Established Knowledge and Why it Matters. Oxford University Press: Oxford.

Schiermeier Q. (2003). Polish science: Poles apart, or together with Europe? Nature. 421: 471-472. doi:10.1038/421471a.

Schiermeier Q. (2017). Poland: Into the light. Nature 542: 507-509 (23 February 2017); doi:10.1038/nj7642-507a.

\section{There is no freedom without responsibility}

ABSTRACT. We analyze the system of organization of science and its change in Poland in the last quarter century, in the context of parallel changes in the world. Based on our experience at the International Institute of Molecular and Cell Biology in Warsaw, but also thanks to good models from other institutions in Poland and abroad, we present our thoughts on the question of how to develop science in Poland. We think that in order to improve the system of science organization in our country and quickly achieve a positive effect, we must use proven models from other countries and positive examples of our own Polish successes. The implementation of these tasks requires courageous political decisions that will provide the scientists with the freedom necessary to work effectively, but will also bind this freedom with responsibility. Thanks to people, who take up this responsibility and take full advantage of the opportunities offered, Poland will have a chance for rapid civilization progress. Investments in science are crucial to the development of each country. 
KEYWORDS: science organization, freedom, responsibility, staff excellence, de-bureaucratization, expert rating system

CYTOWANIE: Kuźnicki, J., Bujnicki, J.M. (2017). Nie ma wolności bez odpowiedzialności. Nauka i Szkolnictwo Wyższe. 2(50): 205-222. DOI: 10.14746/nisw.2017.2.10.

JANUSZ MAREK BUJNICKI - ur. w 1975 r. w Krakowie; profesor nauk biologicznych i kierownik grupy badawczej w Międzynarodowym Instytucie Biologii Molekularnej i Komórkowej w Warszawie i na Uniwersytecie im. Adama Mickiewicza w Poznaniu. W swoich badaniach łączy bioinformatykę, biologię strukturalną i biologię syntetyczną. Jest autorem ponad 300 publikacji, które były cytowane ok. 7 tys. razy. Zdobył dwa granty ERC. Otrzymał wiele stypendiów, wyróżnień i nagród za osiągnięcia naukowe, w tym nagrodę EMBO/HHMI YIP, Nagrodę Narodowego Centrum Nauki, Nagrodę Ministra Nauki i Szkolnictwa Wyższego oraz Nagrodę Prezesa Rady Ministrów, został też odznaczony Krzyżem Kawalerskim Orderu Odrodzenia Polski przez Prezydenta RP. Jest redaktorem wykonawczym czasopisma Nucleic Acids Research. Brał udział w pracach różnych organizacji i ciał doradczych, w tym w ruchu społecznym Obywatele Nauki, w Komitecie Polityki Naukowej i w Grupie Wysokiego Szczebla Mechanizmu Doradztwa Naukowego EU. W 2016 r. został wybrany na członka korespondenta Polskiej Akademii Nauk i obecnie jest najmłodszym członkiem PAN. E-mail: iamb@ genesilico.pl.

JACEK KUŹNICKI - ur. w 1952 r. w Łodzi; profesor nauk biologicznych, dyrektor Międzynarodowego Instytutu Biologii Molekularnej i Komórkowej w Warszawie oraz kierownik Laboratorium Neurodegeneracji tamże od 2001; członek korespondent PAN od 2004. Zainteresowania badawcze: mechanizmy chorób neurodegeneracyjnych, starzenia i długowieczności, regulacja homeostazy wapniowej, biochemia białek. Autor ponad 130 publikacji; H-indeks: 36. Promotor 13 doktoratów. Laureat wielu nagród, m.in. Wydziału II PAN 2013, subsydium profesorskiego FNP 2004-2007, Prezesa Rady Ministrów 2003; odznaczony Krzyżem Oficerskim i Kawalerskim Polonia Restituta 2008, 1998. Członek wielu organizacji, m.in. Komitetu Prognoz Polska 2000 Plus PAN (od 2016 r.), Komitetu Polityki Naukowej (2011-2014), zarządu Europejskiego Towarzystwa Wapniowego (od 2008 r.), Grupy Doradczej 7PR ds. Zdrowia w KE w Brukseli (2006-2011). Kierownik projektów badawczych m.in. w 7PR UE RegPot FishMed (2012-2016), ERA-NET RUS - TargetSOCE (20122014), COMBIOM (2011-2014), ERA-NET NEURON - NeuConnect (2011-2014), RegPot HEALTH-PROT (2009-2012), w 6PR: PROMEMORIA (2005-2009), APOPIS (2004-2006), w 5PR UE: Centrum Doskonałości Biomedycyny Molekularnej (2003-2006). E-mail: jacek.kuznicki@iimcb.gov.pl. 